\title{
Aktualisasi Mitigasi Risiko Bisnis Berdasarkan Prinsip Fiduciary Duty dan Business Judgment Rule
}

\author{
Ghani Satria Hartanto*, Dewi Kania Sugiharti dan Anita Afriana \\ Program Studi Ilmu Hukum, Fakultas Hukum Universitas Padjadajran \\ Penulis korespondensi: ghanisatria_15@yahoo.com
}

\begin{abstract}
ABSTRAK
Proyek besar dalam rangka pembangunan menyebabkan BUMN mengalami kesulitan keuangan, bahkan merugi, input atau keuntungan yang diperoleh dari pembangunan lebih sedikit daripada output atau biaya yang telah digunakan, dalam hal ini direksi bertanggungjawab atas pengelolaan atau pengurusan perusahaan dengan baik mungkin, walaupun dibayang-banyangi oleh berbagai risiko, diantaranya risiko bisnis, maka dari itu direksi perlu melakukan mitigasi risiko agar dapat melaksakan tugas dan fungsinya dengan sebaik mungkin dan memaksimalkan pencapaian maksud dan tujuan pendirian BUMN. Metode pendekatan dalam penelitian ini adalah yuridis normatif yang lebih mengutamakan penelitian kepustakaan. Spesifikasi penelitian bersifat deskriptif. Tahap penelitian dilakukan melalui penelitian kepustakaan yaitu mengumpulkan data sekunder berupa bahan hukum primer, sekunder, dan penelitian lapangan. Hasil penelitian menyimpulkan kerugian yang dialami oleh BUMN yang melakukan kegiatan infrasturktur adalah sulit untuk dihindari, apalagi dalam konteks perusahaan yang maksud dan tujuan adalah mencari keuntungan dan optimalisasi mitigasi risiko dapat terwujud ketika direksi mengimplementasikan prinsipprinsip terkait tugas dan fungsi direksi, terutama prinsip fiduciary duty sebagaimana mestinya, dengan begitu sekalipun keputusan yang diambil mengakibatkan kerugian bagi BUMN.
\end{abstract}

Kata kunci: Direksi, Infrastruktur, Risiko Bisnis.

\section{ABSTRACT}

Large projects in the context of development cause BUMN to experience financial difficulties, even loss, the input or profit obtained from development is less than the output or costs that have been used, in this case the board of directors is responsible for managing or managing the company as well as possible, even though overshadowed by various risks, including business risks, therefore the board of directors needs to mitigate risks in order to carry out their duties and functions as best as possible and maximize the achievement of the goals and objectives of establishing a BUMN. The approach method in this research is normative juridical which prioritizes library research. The research specification is descriptive. The research phase was carried out through library research, namely collecting secondary data in the form of primary, secondary, and field research. The results of the study conclude that the losses suffered by BUMN that carry out infrastructure activities are difficult to avoid, especially in the context of a company whose purpose and objective is to seek profit and optimization of risk mitigation can be realized when the board of directors implements the principles related to the duties and functions of the board of directors, especially the fiduciary duty principle as it should be, even if the decisions taken result in losses for BUMN.

Keywords: Business Risk, Directors, Infrastructure. 


\section{PENDAHULUAN}

Badan Usaha Milik Negara (BUMN) perlu dikelola sebaik mungkin dengan mengimplementasikan prinsip-prinsip pengelolaan perusahaan yang baik dan mematuhi peraturan perundang-undangan terkait, karena dalam pengelolaannya tidak terlepas dari berbagai hal yang dapat menyebabkan adanya kerugian, diantaranya adalah kerugian secara bisnis, tindak pidana korupsi dan kesalahan-kesalahan yang bersifat administratif, selain itu terdapat disharmonisasi antara Undang-Undang Nomor 17 Tahun 2003 tentang Keuangan Negara (UU Keuangan Negara) dengan Undang-Undang Nomor 19 Tahun 2003 tentang Badan Usaha Milik Negara (UU BUMN) yang menyebabkan adanya kerancuan mengenai kerugian keuangan negara.

Mahkamah Konstitusi (MK) pada tahun 2013 melalui Putusan MK Nomor 48/PUUXI/2013 menolak permohonan uji materi terkait UU Keuangan Negara, selain itu, Putusan Mahkamah Agung Nomor 1863/K/Pid.Sus/2010 sebelumnya telah menjadi yurisprudensi yang menjadi rujukan dalam penilaian atau penetapan kerugian keuangan negara. Permasalahan tersebut berdampak kepada kerugian yang dialami oleh BUMN diklasifikasikan sebagai kerugian negara dan berujung pada indikasi adanya tindak pidana korupsi yang dilakukan oleh direksi sebagai pihak yang bertanggungjawab atas pengelolaan BUMN, walaupun dalam dunia usaha, kerugian secara bisnis adalah sesuatu wajar. Berikut ini merupakan beberapa contoh kasus BUMN yang mengalami kerugian secara bisnis.

PT. Wijaya Karya Tbk. (WIKA) mengalami penurunan kinerja keuangan dalam enam bulan pertama pada tahun 2020. Hal ini dapat dilihat dari laba bersih WIKA yang mengalami kontraksi hingga 71,91\% (tujuh puluh satu koma sembilan puluh satu persen) dari Rp. 890.880.000.000 (delapan ratus sembilan puluh miliar delapan ratus delapan puluh juta rupiah) pada semester I 2019 menjadi Rp. 250.410.000.000 (dua ratus lima puluh miliar empat ratus sepuluh juta rupiah). Capaian tersebut diakibatkan oleh menurunnya laba usaha WIKA pada periode tersebut sebesar 37,21\% (tiga puluh tuh koma dua puluh satu persen) (Lestari Ningsih, 2020).

PT. Adhi Karya Tbk. (ADHI) juga mengalami penurunan pendapatan pada semester I tahun 2020, ADHI memperoleh laba bersih sebesar Rp. 11.270.000.000 (sebelas miliar dua ratus tujuh puluh juta rupiah), terjadi penurunan sebesar 94,76\% (sembilan puluh empat koma tujuh puluh enam persen) dari capaian semester I 2019 yang sebesar Rp. 215.000.000.000 (dua ratus lima belas miliar rupiah). Hal ini tidak lepas dari penurunan laba usaha ADHI sebesar 19,75\% (sembilan belas koma tujuh puluh lima persen) (Lestasi Ningsih, 2020), di samping itu, dalam rangka mewujudkan pemerataan ekonomi di Indonesia, perusahaan yang bergerak pada sektor konstruksi tersebut harus melaksanakan program peningkatan infrastuktur yang ditugasi oleh pemerintah.

Pemerintah menekankan bahwa program pembangunan infrastruktur merupakan bagian dari upaya mewujudkan keadilan bagi seluruh rakyat. Pembangunan tidak lagi terfokus di Pulau Jawa, melainkan di seluruh daerah Indonesia, dengan begitu masyarakat dapat melakukan kegiatannya dengan efektif dan efisien (Mikhael Gewati, 2019), maka dibutuhkan dana yang tidak sedikit agar dapat dilaksanakan dengan baik, namun demikian, pembangunan infrastrkutur tersebut dinilai berbagai pihak semakin menambah beban keuangan bagi BUMN terkait.

Berbagai proyek besar dari pemerintah telah menyebabkan sejumlah BUMN mengalami kesulitan keuangan seperti ADHI yang ditugaskan oleh pemerintah melaksanakan proyek Light Rail Transit (LRT) Jakarta, Bogor, Depok dan Bekasi pada tahun 2016. Pemerintah menyuntikkan dana Penyertaan Modal Negara (PMN) sebesar 1.500.000.000.000 (satu triliun lima ratus miliar rupiah) untuk melaksanakan proyek tersebut. Tiga tahun kemudian, proyek 
ini menyebabkan kas ADHI minus hingga Rp. 2.500.000.000.000 (dua triliun koma lima ratus miliar rupiah) (Ali Akhmad Noor Hidayat, 2019). Pembangunan tersebut kerap kali tidak menjanjikan keuntungan dalam waktu dekat, bahkan merugi, dengan kata lain, input atau keuntungan yang diperoleh dari pembangunan tersebut lebih sedikit daripada output atau biaya yang telah digunakan dalam pembangunan yang dilakukan oleh BUMN.

Keseluruhan kasus tersebut memperlihatkan bahwa BUMN memiliki kewajiban untuk memperoleh keuntungan dan juga melaksanakan penugasan yang diperintahkan oleh pemerintah, sekalipun dalam implementasinya berdampak kepada keuangan perusahaan BUMN yang bersangkutan, dalam hal ini tentu saja direksi sebagai pihak yang bertanggungjawab atas pengelolaan atau pengurusan perusahaan harus mengupayakan agar keseluruhan kewajiban tersebut dapat dilaksanakan dengan baik mungkin, walaupun dalam melaksanakan tugas dan kewajibannya dibayang-banyangi oleh berbagai risiko.

Berkaitan dengan tugas pengurusan perseroan yang dipercayakan kepada direksi, perlu diperhatikan bahwa tidak wajar dan tidak adil, mengharapkan apalagi mewajibkan direksi untuk menjamin bahwa perseroan yang pengurusannya ditugaskan kepada direksi pasti untung, oleh karena itu, dalam Undang-Undang Nomor 40 Tahun 2007 tentang Perseroan Terbatas (UU Perseroan Terbatas) disebutkan, direksi hanya dapat dimintai pertanggungjawaban kerugian perseroan karena kesalahan dan kelalaian direksi karena tidak menjalankan tugasnya dengan itikad baik dan penuh tanggugjawab (Sentosa Sembiring, 2012), berdasarkan business judgement rule yang diatur pada Pasal 97 ayat (5) UU Perseroan Terbatas, yaitu:

"Anggota direksi tidak dapat dipertanggungjawabkan atas kerugian sebagaimana dimaksud pada ayat (3) apabila dapat membuktikan:

a. $\quad$ kerugian tersebut bukan karena kesalahan atau kelalaiannya;

b. telah melakukan pengurusan dengan itikad baik dan kehati-hatian untuk kepentingan dan sesuai dengan maksud dan tujuan perseroan;

c. tidak mempunyai benturan kepentingan baik langsung maupun tidak langsung atas tindakan pengurusan yang mengakibatkan kerugian; dan

d. telah mengambil tindakan untuk mencegah timbul atau berlanjutnya kerugian tersebut."

Business judgment rule dapat menjadi pelindung bagi direksi dalam melaksanakan tugas dan fungsinya, tanpa harus harus mengkhawatirkan berbagai risiko yang dapat menyebabkan terjadinya kerugian pada perusahaan yang dikelolanya. Business judgment rule mendorong direksi untuk lebih berani mengambil risiko daripada terlalu berhati-hati, sehingga perusahaan tidak jalan (Sentosa Sembiring, 2012), maka dari itu, business judgement rule seyogyanya dapat melindungi direksi dalam perusahaan BUMN yang kerap mengalami kerugian secara bisnis, namun sebelum itu, direksi perlu melakukan upaya terbaik bagi perusahaan karena dalam melaksanakan tugasnya, direksi didasarkan kepada prinsip fiduciary duty yang mengharuskan direksi untuk mengerjakan atau melakukan yang terbaik bagi perseroan. Direksi harus menghormati kepercayaan yang diberikan oleh perseroan melalui pengangkatan Rapat Umum Pemegang Saham (RUPS) (Man Sastrawidjaya, 2012).

Upaya tersebut adalah dengan melakukan mitigasi risiko agar direksi dapat melaksakan tugas dan fungsinya dengan sebaik mungkin di samping memaksimalkan pencapaian maksud dan tujuan pendirian BUMN, namun dalam hal ini belum ada peraturan perundang-undangan yang mengatur mitigasi risiko pada BUMN, adapun peraturan terkait risiko pada BUMN adalah Peraturan Menteri Badan Usaha Milik Negara Nomor: Per-01/MBU/2011 Tentang Penerapan Tata Kelola Perusahaan Yang Baik (Good Corporate Governance) pada Badan Usaha Milik Negara yang telah diubah oleh Peraturan Menteri Negara Badan Usaha Milik Negara Nomor: Per-09/Mbu/2012 Tentang Perubahan Atas Peraturan Menteri Negara Badan Usaha Milik Negara Nomor Per-01/Mbu/2011 Tentang Penerapan Tata Kelola Perusahaan Yang Baik (Good Corporate Governance) pada Badan Usaha Milik Negara (PERMEN BUMN 
Good Corporate Governance) yang mengatur manajemen risiko. Pasal 25 PERMEN BUMN Good Corporate Governance mengatur:

1) Direksi, dalam setiap pengambilan keputusan/tindakan, harus mempertimbangkan risiko usaha.

2) Direksi wajib membangun dan melaksanakan program manajemen risiko korporasi secara terpadu yang merupakan bagian dari pelaksanaan program GCG.

3) Pelaksanaan program manajemen risiko dapat dilakukan, dengan:

a. membentuk unit kerja tersendiri yang ada di bawah direksi; atau

b. memberi penugasan kepada unit kerja yang ada dan relevan untuk menjalankan fungsi manajemen risiko.

4) Direksi wajib menyampaikan laporan profil manajemen risiko dan penanganannya bersamaan dengan laporan berkala perusahaan".

Peraturan tersebut mewajibkan direksi pada BUMN untuk membangun dan melaksanakan program manajemen risiko dengan membentuk unit kerja tersendiri yang berada di bawah direksi atau memberi penugasan kepada unit kerja yang sudah ada dalam menjalankan fungsi manajemen risiko. Manajemen risiko merupakan suatu usaha untuk mengetahui, menganalisis serta mengendalikan risiko dalam setiap kegiatan perusahaan dengan tujuan untuk memperoleh efektivitas dan efisiensi yang lebih tinggi (Herman Darmawi, 2019), tetapi tidak mengatur upaya yang lebih konkrit, yaitu mitigasi risiko. Pencegahan pada manajemen risiko saja tidak menjamin BUMN dapat terhindar dari kerugian, risiko akan tetap muncul, walaupun segala tindakan pencegahan sudah dilakukan, maka direksi harus melakukan mitigasi (Hotasi Nababan, 2018).

Berdasarkan latar belakang yang telah diuraikan maka dirumuskan suatu permasalahan yakni bagaimanakah urgensi mitigasi risiko bisnis pada BUMN dalam rangka pembangunan infrastruktur nasional berdasarkan business judgment rule dan bagaimanakah optimalisasi direksi dalam melakukan mitigasi risiko bisnis berdasarkan prinsip fiduciary duty.

\section{METODOLOGI PENELITIAN}

Penelitian hukum merupakan suatu kegiatan ilmiah, yang didasarkan pada metode, sistematika dan pemikiran tertentu, yang bertujuan untuk mempelajari satu atau beberapa gejala hukum tertentu, dengan jalan menganalisanya. (Soerjono Soekanto, 2014). Metode penelitian yang digunakan adalah yuridis normatif, yaitu metode penelitian hukum yang mengutamakan cara meneliti bahan pustaka atau yang disebut data sekunder berupa hukum positif (Soerjono Soekanto \& Sri Mamudji, 2003), dengan mengkaji data sekunder. Tahapan penelitian dalam penulisan jurnal ini dilakukan melalui studi kepustakaan dan studi lapangan dengan teknik pengumpulan data berupa studi dokumen dan wawancara. Metode analisis data dalam penulisan jurnal ini menggunakan metode yuridis kualitiatif.

Metode pendekatan yang digunakan dalam penelitian ini adalah yuridis normatif, yaitu metode penelitian hukum yang mengutamakan cara meneliti bahan pustaka atau yang disebut data sekunder berupa hukum positif. Spesifikasi yang digunakan dalam penelitian ini bersifat deskriptif analisis yang dimaksudkan untuk memberikan data yang seteliti mungkin tentang manusia, keadaan atau gejala-gejala lainnya, maksudnya adalah terutama untuk mempertegas hipotesa-hipotesa, agar dapat membantu di dalam memperkuat teori-teori lama, atau di dalam kerangka menyusun teori-teori baru.

Teknik pengumpulan data yang dilakukan dalam penelitian ini adalah penelitian kepustakaan dengan memperoleh data sekunder demi mendapatkan landasan teoretis yang dianggap relevan untuk dijadikan bahan dalam penelitian ini dengan menggunakan bahanbahan hukum primer, sekunder, dan tersier yang berhubungan dengan pokok permasalahan. 
Metode analisis data yang dilakukan dalam penelitian ini adalah normatif kualitatif, yaitu berdasarkan peraturan perundang-undangan terkait, khususnya UU BUMN dan UU Keuangan Negara.

\section{HASIL DAN PEMBAHASAN}

\section{Urgensi Mitigasi Risiko Bisnis Pada BUMN dalam Rangka Pembangunan Infrastruktur Nasional Berdasarkan Business Judgment Rule}

Pasal 33 ayat (3) Undang-Undang Dasar 1945 (UUD 1945) mengamanatkan, "Bumi dan air dan kekayaan alam yang terkandung di dalamnya dikuasai oleh negara dan dipergunakan untuk sebesar-besar kemakmuran rakyat" dan Pasal 33 ayat (4) UUD 1945 mengamanatkan:

"Perekonomian nasional diselenggarakan berdasar atas demokrasi ekonomi dengan prinsip kebersamaan, efisiensi berkeadilan, berkelanjutan, berwawasan lingkungan, kemandirian, serta dengan menjaga keseimbangan kemajuan dan kesatuan ekonomi nasional".

Huruf a konsiderans UU BUMN mengatakan, "bahwa Badan Usaha Milik Negara merupakan salah satu pelaku kegiatan ekonomi dalam perekonomian nasional berdasarkan demokrasi ekonomi" kemudian huruf b konsiderans UU 19/2003 mengatakan, "bahwa Badan Usaha Milik Negara mempunyai peranan penting dalam penyelenggaraan perekonomian nasional guna mewujudkan kesejahteraan masyarakat.". Hal ini menunjukkan bahwa BUMN merupakan pihak yang ditunjuk untuk mewujudkan kesejahteraan bagi masyarakat, lebih lenjut dapat dilihat pada Angka I Penjelasan UU BUMN yang menyatakan bahwa:

"Memajukan kesejahteraan bagi seluruh rakyat sebagaimana diamanatkan dalam Pembukaan UUD 1945 yang selanjutnya lebih rinci diatur dalam Pasal 33 UUD 1945 merupakan tugas konstitusional bagi seluruh komponen bangsa. Dalam kaitan di atas, dirasa perlu untuk meningkatkan penguasaan seluruh kekuatan ekonomi nasional baik melalui regulasi sektoral maupun melalui kepemilikan negara terhadap unit-unit usaha tertentu dengan maksud untuk memberikan manfaat yang sebesar-besarnya bagi kemakmuran rakyat.

BUMN yang seluruh atau sebagian besar modalnya berasal dari kekayaan negara yang dipisahkan, merupakan salah satu pelaku ekonomi dalam sistem perekonomian nasional, di samping usaha swasta dan koperasi. Dalam menjalankan kegiatan usahanya, BUMN, swasta dan koperasi melaksanakan peran saling mendukung berdasarkan demokrasi ekonomi." Angka II Penjelasan UU BUMN menyatakan:

"Dalam sistem perekonomian nasional, BUMN ikut berperan menghasilkan barang dan/atau jasa yang diperlukan dalam rangka mewujudkan sebesar-besarnya kemakmuran masyarakat. Peran BUMN dirasakan semakin penting sebagai pelopor dan/atau perintis dalam sektor-sektor usaha yang belum diminati usaha swasta. Di samping itu, BUMN juga mempunyai peran strategis sebagai pelaksana pelayanan publik, penyeimbang kekuatan-kekuatan swasta besar, dan turut membantu pengembangan usaha kecil/koperasi. BUMN juga merupakan salah satu sumber penerimaan negara yang signifikan dalam bentuk berbagai jenis pajak, dividen dan hasil privatisasi."

Pelaksanaan peran BUMN tersebut diwujudkan dalam kegiatan usaha pada hampir seluruh sektor perekonomian, seperti sektor pertanian, perikanan, perkebunan, kehutanan, manufaktur, pertambangan, keuangan, pos dan telekomunikasi, transportasi, listrik, industri dan perdagangan, serta konstruksi.".

Uraian di atas memperlihatkan adanya urgensi menciptakan kesejahteraan bagi masyarakat yang sangat ditekankan oleh negara oleh berbagai pihak, dalam hal ini BUMN, swasta dan koperasi yang didorong untuk dapat bersinergi satu sama lain, namun peran BUMN disini sangatlah strategis, dapat dilihat pada maksud dan tujuan pendirian BUMN sendiri, yaitu:

a. Memberikan sumbangan bagi perkembangan perekonomian nasional pada 
umumnya dan penerimaan negara pada khususnya;

b. Mengejar keuntungan;

c. Menyelenggarakan kemanfaatan umum berupa penyediaan barang dan/atau jasa yang bermutu tinggi dan memadai bagi pemenuhan hajat hidup orang banyak;

d. Menjadi perintis kegiatan-kegiatan usaha yang belum dapat dilaksanakan oleh sektor swasta dan koperasi;

e. Turut aktif memberikan bimbingan dan bantuan kepada pengusaha golongan ekonomi lemah, koperasi, dan masyarakat.".

Upaya mewujudkan kesejahteraan bagi masyarakat merupakan hal yang tidak mudah dan tidak dapat dilihat dalam jangka waktu dekat, tetapi perlu dilihat di kemudian hari, selain itu membutuhkan biaya yang tidak sedikit, bahkan membutuhkan pengorbanan dalam mewujudkannya, dalam konteks ekonomi dan perusahaan dapat diasumsikan kerugian, maka dari itu tugas BUMN dalam hal ini tidaklah mudah, terlebih BUMN merupakan badan usaha yang juga dibentuk untuk mencari keuntungan dan memberikan sumbangan bagi penerimaan negara. BUMN berdasarkan bentuknya terbagi menjadi persero dan perum, berdasarkan Pasal 12 huruf UU BUMN, "Maksud dan tujuan pendirian Persero adalah menyediakan barang dan/atau jasa yang bermutu tinggi dan berdaya saing kuat dan mengejar keuntungan guna meningkatkan nilai perusahaan." dan Pasal 36 UU BUMN ayat (1) mengatur:

"Maksud dan tujuan Perum adalah menyelenggarakan usaha yang bertujuan untuk kemanfaatan umum berupa penyediaan barang dan/atau jasa yang berkualitas dengan harga yang terjangkau oleh masyarakat berdasarkan prinsip pengelolaan perusahaan yang sehat.".

Penelitian ini berupaya membahas BUMN dalam bentuk persero, secara lebih spesifik pada BUMN yang melakukan kegiatan pembangunan infrastruktur seperti ADHI dan WIKA, maka dari itu dalam hal terjadinya kerugian, perlu juga melihat kepada UU Perseroan Terbatas, dalam hal terjadinya kerugian, direksi bertanggungjawab penuh secara pribadi yang diakibatkan oleh kesalahan atau kelalaiannya dalam menjalankan tugasnya, tetapi jika kerugian tersebut tidak diakibatkan oleh adanya kesalahan atau kelalaian direksi atau murni karena adanya risiko bisnis, berlaku prinsip business judgement rule.

Prinsip business judgement rule seharusnya dapat melindungi direksi sebagai pihak yang memiliki peran sentral dalam mengatasi masalah risiko yang mengancam keberlangsungan perusahaan, namun demikian, pengadilan masih tetap dapat melakukan penilaian terhadap putusan direksi. Hakim dalam hal ini menilai apakah putusan yang diambil oleh direksi memang dapat dikategorikan sebagai business judgement rule atau tidak. Prinsip business judgement rule menegaskan, bahwa putusan direksi tidak dapat diganggu gugat oleh siapapun, walaupun di kemudian hari diketahui bahwa putusan tersebut justru merugikan perusahaan, sepanjang putusan tersebut memenuhi syarat sebagai berikut (Sentosa Sembiring, 2012):

1. Putusan sesuai hukum yang berlaku.

2. Dilakukan dengan itikad baik.

3. Dilakukan dengan tujuan yang benar.

4. Putusan tersebut mempunyai dasar-dasar yang rasional.

5. Dilakukan dengan kehati-hatian.

6. Dilakukan dengan cara yang layak dipercayainya sebagai yang terbaik bagi perseroan.

Doktrin ini lebih melindungi direksi, tetapi masih dalam koridor hukum perseroan yang umum bahwa pengadilan dapat melakukan penilaian terhadap setiap putusan, termasuk putusan bisnis yang sudah disetujui oleh RUPS, sepanjangan untuk memutuskan apakah putusan tersebut sesuai dengan hukum yang berlaku atau tidak, akan tetapi tidak untuk menilai apakah sesuai atau tidak dengan kebijakan bisnis, adapun latar belakang munculnya doktrin ini, karena di antara semua pihak dalam perseroan, sesuai dengan kedudukannya selaku direksi, maka direksilah yang berwenang untuk memutuskan apa yang terbaik bagi perseroan, bila terjadi 
kerugian kerena putusan bisnis, dalam batas-batas tertentu masih dapat ditoleransi mengingat tidak semua bisnis harus mendapat untung (Sentosa Sembiring, 2012).

Upaya mewujudkan kesejahteraan bagi masyarakat terus dilakukan dan merupakan bagian dari visi dan misi pembangunan, dimuat dalam Rencana Pembangunan Jangka Menengah Nasional (RPJMN) yang saat ini diatur oleh Peraturan Presiden Nomor 18 Tahun 2020 Tentang Rencana Pembangunan Jangka Menengah Nasional Tahun 2020-2024 (Perpres RPJMN), adapun fungsi RPJMN menurut Pasal 2 ayat (3) Perpres RPJMN adalah sebagai:

1. Pedoman bagi Kementerian/Lembaga dalam menyusun Rencana Strategis Kementerian/ Lembaga;

2. Bahan penyusunan dan penyesuaian RPJM Daerah dengan memperhatikan tugas dan fungsi pemerintah daerah dalam mencapai sasaran Nasional yang termuat dalam RPJM Nasional;

3. Pedoman Pemerintah dalam menyusun Rencana Kerja Pemerintah;

4. Acuan dasar dalam pemantauan dan evaluasi pelaksanaan RPJM Nasional.

Lampiran II Perpres RPJMN memuat 41 (empat puluh satu) proyek prioritas strategis (major project) RPJMN Tahun 2020-2024, dimana 25 (dua puluh lima) diantaranya melibatkan BUMN sebagai pelaksana proyek dan 1 (satu) diantaranya adalah proyek "Infrastruktur TIK untuk Mendukung Transformasi Digital", walaupun demikian, tidak menutup kemungkinan adanya keterlibatan BUMN yang melakukan kegiatan pembangunan infrastruktur dalam proyek lainnya, karena banyak proyek yang terkait dengan urgensi penyediaan sarana atau fasilitas yang memadai, artinya artinya BUMN di bidang infrastruktur memiliki peran yang sangat strategis.

Pembangunan infrastruktur yang dilakukan dalam rangka mensejahterakan masyarakat dan RPJMN memiliki keterkaitan satu sama lain, dapat dilihat pada laporan tahunan WIKA terkait RPJMN sebelumnya yang menjelaskan (PT. Wijaya Karya, 2016):

"Melalui RPJMN 2015-2015, pemerintah melakukan percepatan pertumbuhan ekonomi dengan menambah kuantitas dan perbaikan kualitas infrastruktur melalui pendekatan berbagai dimensi, dalam RPJMN tersebut sasaran pembangunan ekonomi dan kesejahteraan masyarakat bidang infrastruktur dilakukan dengan meneruskan pembangunan dan pasokan infrasturktur. RPJMN dalam infrastruktur ditujukan untuk menambah kuantitas dan kualitas berbagai prasarana penunjuang pembangunan seperti jalan raya, jalan kereta api, pelabuhan laut, pelabuhan udara, listrik, irigasi, air bersih dan sanitasi serta pos dan telekomunikasi.

Keterkaitan tersebut juga dapat dilihat pada pelaksanaan RPJMN pada ADHI sebagai BUMN yang melakukan kegiatan pembangunan infrastruktur. ADHI melalui pembangunan infrastruktur ADHI juga turut membantu kesejahteraan dan pemerataan ekonomi masyarakat terutama di daerah pelosok (PT. Adhi Karya, 2019), dengan begitu dapat diketahui bahwa infrasrtuktur yang baik merupakan hal yang sangat penting dalam upaya mencapai kesejahteraan masyarakat, dengan kata lain, ketersediaan fasilitas sangatlah dibutuhkan untuk mendukung kegiatan perekonomian masyarakat.

Pembangunan infrastruktur menghadapi tiga dimensi permasalahan. Pertama, membutuhkan invetasi yang cukup besar, waktu pengembalian modal yang panjang, pemanfaatan teknologi tinggi, perencanaan dan implementasi perlu waktu panjang untuk mencapai skala ekonomi yang tertentu. Kedua, pembangunan menjadi prasyarat bagi berkembangnya kesempatan dan peluang baru di berbagai bidang kehidupan. Ketiga, adanya persaingan global dan sekaligus memenuhi permintaan investor baik dari dalam maupun luar negeri. Ditambah lagi dengan adanya 2 (dua) matra yang harus dimiliki dalam penyediaan infrastruktur, yaitu matra fisik dan matra pelayanan. Infrastruktur tidak selesai dibangun secara fisik saja, namun menuntut adanya operasional dengan mengedepankan kualitas pelayanan jasa dan efektivitas pengelolaan infrastruktur. Melihat begitu banyaknya peran maupun dimensi 
permasalahan serta tantangan dalam pembangunan infrastruktur, maka perlu diupayakan pencegahan guna meminimalisir munculnya permasalahan (Abdul Haris, 2009), berdasarkan hal itu dapat diketahui pula, bahwa kerugian yang dialami oleh BUMN yang melakukan kegiatan infrasturktur adalah sulit untuk dihindari, apalagi dalam konteks perusahaan yang maksud dan tujuan adalah mencari keuntungan.

\section{Optimalisasi Direksi dalam Melakukan Mitigasi Risiko Bisnis Berdasarkan Prinsip Fiduciary Duty}

Pengelolaan perusahaan tidak terlepas dari berbagai risiko yang dapat menganggu kinerja perusahaan, maka risiko-risiko tersebut harus diketahui dan diantasipasi secepat mungkin sebelum akhirnya terjadi dan mengakibatkan kerugian terhadap perusahaan, terjadinya kerugian sangat berkorelasi dengan risiko dan risiko tersebut perlu diketahui untuk dapat dicegah. Upaya pencegahan yang selama ini dilakukan oleh perusahaan, khususnya BUMN adalah dengan melakukan manajemen risiko sebagaimana diatur dalam Pasal 25 PERMEN BUMN Good Corporate Govenance, yaitu:

(1) Direksi, dalam setiap pengambilan keputusan/tindakan, harus mempertimbangkan risiko usaha.

(2) Direksi wajib membangun dan melaksanakan program manajemen risiko korporasi secara terpadu yang merupakan bagian dari pelaksanaan program GCG.

(3) Pelaksanaan program manajemen risiko dapat dilakukan, dengan:

a. membentuk unit kerja tersendiri yang ada di bawah direksi; atau

b. memberi penugasan kepada unit kerja yang ada dan relevan untuk menjalankan fungsi manajemen risiko.

(4) Direksi wajib menyampaikan laporan profil manajemen risiko dan penanganannya bersamaan dengan laporan berkala perusahaan.

Pasal tersebut mengatur bahwa dalam melakukan pengambilan keputusan, direksi harus senantiasa mempertimbangkan segala risiko usaha dengan melaksanakan manajemen risiko, karena direksi adalah organ perseroan yang berwenang dan bertanggung jawab penuh atas pengurusaan perseroan untuk kepentingan perseroan, sesuai dengan maksud dan tujuan perseroan, baik di dalam maupun di luar pengadilan sesuai dengan ketentuan anggaran dasar (Arus Akbar Silondae \& Andi Fariana, 2013).

baik dengan membentuk unit kerja tersendiri maupun menugaskan kepada unit kerja yang ada dan relevan untuk melaksanakan manajemen risiko, sesuai dengan tugas utama direksi yang diantaranya adalah mengelola kegiatan perusahaan agar tujuan perusahaan dapat tercapai, melakukan pembukuan atas kekayaan perusahaan dan mewakili perusahaan dalam melakukan perbuatan hukum, sebagaimana ditegaskan oleh Pasal 1 angka 5 UU Perseroan Terbatas, bahwa:

"Direksi adalah Organ Perseroan yang berwenang dan bertanggung jawab penuh atas pengurusan Perseroan untuk kepentingan Perseroan, sesuai dengan maksud dan tujuan Perseroan serta mewakili Perseroan, baik di dalam maupun di luar pengadilan sesuai dengan ketentuan anggaran dasar."

Uraian di atas memperlihatkan bahwa direksi memiliki peran yang sangat penting dalam pengelolaan perusahaan agar terhindar dari berbagai risiko dan diharuskan melaksanakan manajemen risiko yang dalam hal ini Peneliti fokuskan kepada risiko bisnis. Peneliti berpendapat, bahwa manajemen risiko belum dapat menjamin bahwa perusahaan dapat menghindari risiko bisnis. Perusahaan tidak dapat memprediksi secara pasti apa yang dapat terjadi dan kemudian berpengaruh terhadap pengelolaan perusahaan.

Terdapat banyak faktor yang dapat mempengaruhi pengelolaan perusahaan, baik secara langsung maupun tidak langsung, salah satu contoh yang sangat jelas adalah pandemi yang 
terjadi saat ini, virus corona tidak terprediksikan dapat tersebar dengan begitu cepat dan memaksa kita untuk mengurangi segala kegiatan yang melibatkan interaksi satu sama lain, selain itu, contoh risiko bisnis lainnya adalah inflasi, ketidakstabilan perusahaan, daya beli masyarakat yang sedang menurun dan lain-lain. Risiko bisnis pada hakikatnya menyebabkan terhambatnya kegiatan perekonomian dan kerugian sebagaimana telah diuraiakan sebelumnya.

Risiko bisnis sangatlah berpengaruh terhadap pengelolaan atau pengurusan perusahaan dan merupakan risiko yang memerlukan perhatian lebih, tanpa mengesampingkan pencegahan terhadap risiko-risiko lainnya. Kemungkinan terjadinya risiko bisnis tersebut perlu diminimalisir dengan dilaksanakannya mitigasi risiko, karena pencegahan dengan manajemen risiko saja tidak dapat menjamin BUMN dapat terhindar dari kerugian yang diakibatkan oleh terjadinya risiko bisnis. Hal ini memperlihatkan bahwa direksi memiliki tanggung jawab yang besar untuk menjamin bahwa perusahaan yang dikelolanya berjalan dengan baik dan terhindar dari risiko bisnis, di samping kondisi bahwa dalam konteks mencari keuntungan, BUMN berbeda dengan perusahaan swasta.

Direksi berpotensi harus mempertanggungjawabkan kerugian yang dialami oleh BUMN secara pribadi dalam hal perusahaan mengalami kerugian, dengan alasan kesalahan atau kelalaiannya mengakibatkan perusahaan mengalami kerugian. Hal tersebut tentu harus dihindari karena dalam hal ini terdapat prinsip business judgement rule. Latar belakang munculnya doktrin atau prinsip ini, karena di antara semua pihak dalam perseroan, sesuai dengan kedudukannya, maka direksilah yang berwenang untuk memutuskan apa yang terbaik bagi perseroan, bila terjadi kerugian kerena putusan bisnis, dalam batas-batas tertentu masih dapat ditoleransi mengingat tidak semua bisnis harus mendapatkan keuntungan. Pengaturan prinsip business judgement rule terdapat dalam Pasal 97 ayat (5) UU Perseroan Terbatas, yaitu: "Anggota direksi tidak dapat dipertanggungjawabkan atas kerugian sebagaimana dimaksud pada ayat (3) apabila dapat membuktikan:

a. kerugian tersebut bukan karena kesalahan atau kelalaiannya;

b. telah melakukan pengurusan dengan itikad baik dan kehati-hatian untuk kepentingan dan sesuai dengan maksud dan tujuan perseroan;

c. tidak mempunyai benturan kepentingan baik langsung maupun tidak langsung atas tindakan pengurusan yang mengakibatkan kerugian; dan

d. telah mengambil tindakan untuk mencegah timbul atau berlanjutnya kerugian tersebut."

Penulis berpendapat, bahwa persyaratan prinsip business judgement rule tersebut dapat terpenuhi jika prinsip terkait pelaksanaan tugas dan wewenang direksi sudah diimplementasikan dengan baik, karena dalam hal ini Penulis melihat adanya korelasi antara 6 (enam) persyaratan terkait implementasi prinsip business judgement rule di atas dengan beberapa prinsip terkait pelaksanaan tugas dan fungsi direksi yang dapat dilihat pada uraian berikut ini.

\section{Putusan Sesuai Hukum yang Berlaku}

Syarat "putusan sesuai hukum yang berlaku" berkorelasi dengan prinsip ultra vires mengenai pelaksanaan tugas dan wewenang direksi yang membatasi wewenang direksi dalam perusahaan ketika melakukan tindakan hukum atas nama perusaahaan yang bersangkutan, pembatasan yang dimaksud tentunya mengacu kepada wewenang direksi yang diatur dalam UU Perseroan Terbatas dan PERMEN BUMN Good Corporate Governance dalam konteks upaya pencegahan risiko bisnis yang dilaksanakan oleh direksi, maupun peraturan perundangundangan terkait. Prinsip tersebut melarang direksi untuk melakukan suatu tindakan di luar kewenangannya dan jika melanggar, tindakan direksi dapat diklasifikasikan sebagai ultra vires, maka dari itu dengan terpenuhinya prinsip ultra vires, syarat "putusan sesuai hukum yang 
berlaku" dalam prinsip business judgement rule telah terpenuhi.

\section{Dilakukan dengan Itikad Baik}

Syarat "dilakukan dengan itikad baik" berkorelasi dengan prinsip duty of loyalty mengenai pelaksanaan tugas dan wewenang direksi yang mengatakan bahwa direksi harus melaksanakan manajemen dan melakukan tindakan hukum atas nama perusahaan semata-mata untuk kepentingan perusahaan dan merujuk kepada itikad baik, dalam melakukan tindakan atas atas nama perusahaan tersebut sudah seharusnya tidak melibatkan kepentingan pribadi ataupun kepentingan pihak atau kelompok tertentu, maka dari itu, dengan terpenuhinya prinsip ini, syarat "dilakukan dengan itikad baik" dalam prinsip business judgement rule telah terpenuhi.

\section{Dilakukan dengan Tujuan yang Benar}

Syarat "dilakukan dengan tujuan yang benar" juga berkorelasi dengan prinsip duty of loyalty mengenai pelaksanaan tugas dan wewenang direksi yang mengatakan, bahwa direksi harus melaksanakan manajemen dan melakukan tindakan hukum atas nama perusahaan semata-mata untuk kepentingan perusahaan dan merujuk kepada itikad baik, dalam melakukan tindakan atas atas nama perusahaan tersebut sudah seharusnya tidak melibatkan kepentingan pribadi ataupun kepentingan pihak atau kelompok tertentu, maka dari itu, dengan terpenuhinya prinsip ini, syarat "dilakukan dengan tujuan yang benar" dalam prinsip business judgement rule telah terpenuhi.

\section{Putusan Tersebut Mempunyai Dasar-Dasar yang Rasional}

Syarat "putusan tersebut mempunyai dasar-dasar yang rasional" berkorelasi dengan prinsip duty of skill mengenai pelaksanaan tugas dan wewenang direksi yang mengatakan, bahwa direksi haruslah seseorang yang memiliki kemampuan dalam mengelola atau mengurus perusahaan dan menerapkan kehati-hatian dalam mengambil atau membuat suatu keputusan atas nama perusahaan. Kemampuan dalam mengelola perusahaan tersebut tentu dapat memberikan dasar pertimbangan yang matang dalam setiap tindakan atau keputusannya dan dilakukan juga dengan penuh kehati-hatian, sehingga keputusan yang dibuat oleh direksi merupakan tindakan yang memiliki dasar-dasar yang rasional, maka dari itu, dengan terpenuhinya prinsip ini, syarat "putusan tersebut mempunyai dasar-dasar yang rasional" dalam prinsip business judgement rule telah terpenuhi.

\section{Dilakukan dengan Kehati-Hatian}

Syarat "dilakukan dengan kehati-hatian" berkorelasi dengan prinsip duty of care mengenai pelaksanaan tugas dan wewenang direksi yang mengatakan, bahwa direksi harus selalu berhatihati dalam melaksanakan tugasnya, tidak terkecuali dalam hal pengambilan keputusan terkait hal-hal yang dinilai penting karena dapat mempengaruhi kondisi perusahaaan, salah satunya mengenai upaya pencegahan risiko, dengan adanya kehati-hatian dalam setiap pengambilan keputusan dapat meminimalisasi risiko bisnis yang mengancam keberlangsungan perusahaan. Diharapkan dengan diimplementasikannya prinsip duty of care oleh direksi, seluruh tujuan mitigasi risiko tersebut dapat tercapai dan syarat "dilakukan dengan kehati-hatian" dalam prinsip business judgement rule dapat terpenuhi.

\section{Dilakukan dengan Cara yang Layak Dipercayainya Sebagai yang Terbaik Bagi Perseroan}

Syarat "dilakukan dengan cara yang layak dipercayainya sebagai yang terbaik bagi perseroan" berkorelasi dengan prinsip fiduciary duty mengenai pelaksanaan tugas dan wewenang direksi yang mengatakan, bahwa direksi harus melaksanakan tugas dan fungsinya dengan sebaik- 
baiknya karena direksi merupakan organ perusahaan yang dipercayai melakukan pengurusan atau pengelolaan perusahaan. Kepercayaan tersebut sudah seharusnya membuat direksi lebih bertanggungjawab dalam melaksanan tugasnya, sehingga segala tindakan atau keputusan yang dibuatnya memang diperuntukkan demi kebaikan atau kepentingan perusahaan, maka dari itu, dengan terpenuhinya prinsip ini, syarat "dilakukan dengan cara yang layak dipercayainya sebagai yang terbaik bagi perseroan" dalam prinsip business judgement rule telah terpenuhi.

Peneliti berpendapat bahwa fiduciary duty merupakan prinsip yang paling krusial atau penting terkait permasalahan ini karena prinsip fiduciary duty merupakan prinsip yang berkorelasi dengan prinsip-prinsip lainnya, sebagaimana diuraiakan sebelumnya oleh Arus Akbar Silondae \& Andi Fariana, bahwa tiga unsur penting dalam prinsip fiduciary duties adalah terpenuhinya prinsip duty of skills, duty of loyalty dan doctrine of corporate opportunity, dengan terpenuhinya prinsip terkait pelaksanaan tugas dan wewenang direksi, diharapkan tidak hanya dapat mengoptimalkan upaya mitigasi risiko dan prinsip business judgement rule dapat diimplementasikan.

Keseluruhan uraian di atas dapat memperlihatkan, bahwa optimalisasi mitigasi risiko dapat terwujud ketika direksi mengimplementasikan prinsip-prinsip terkait tugas dan fungsi direksi, terutama prinsip fiduciary duty sebagaimana mestinya, dengan begitu sekalipun keputusan yang diambil mengakibatkan kerugian bagi BUMN, direksi tidak harus mempertanggungjawabkan keputusan tersebut secara pribadi karena dilindungi oleh prinsip business judgement rule dengan tetap memperhatikan ketentuan Pasal 97 ayat (3) UU Perseroan Terbatas dalam kondisi kerugian diakibakan oleh kesalahan atau kelalaian direksi.

\section{KESIMPULAN DAN SARAN}

Berdasarkan pembahasan di atas, dapat disimpulkan bahwa bahwa kerugian yang dialami oleh BUMN yang melakukan kegiatan infrasturktur adalah sulit untuk dihindari, apalagi dalam konteks perusahaan yang maksud dan tujuan adalah mencari keuntungan dan optimalisasi mitigasi risiko dapat terwujud ketika direksi mengimplementasikan prinsip-prinsip terkait tugas dan fungsi direksi, terutama prinsip fiduciary duty sebagaimana mestinya, dengan begitu sekalipun keputusan yang diambil mengakibatkan kerugian bagi BUMN.

Sebaiknya Menteri BUMN mengatur mekanisme yang lebih jelas mengenai mitigasi risiko bisnis pada BUMN, karena direksi BUMN memiliki tugas yang berat di samping harus mengelola perusahaan direksi juga harus menanggung secara pribadi kerugian yang diakibatkan oleh keputusannya, walaupun terdapat prinsip business judgement rule dengan mengedepankan aspek hukum perusahaan dibandingkan aspek hukum pidana, sehingga direksi lebih berani untuk mengambil risiko terkait keputusan bisnisnya, agar potensi keuntungan yang dapat diperoleh oleh BUMN semakin besar dengan tetap menerapkan itikad baik.

\section{DAFTAR PUSTAKA}

Hidayat, A.A.N. (2019). Sri Mulyani Suntik Rp 17,7 T untuk BUMN, Ekonom Beri Peringatan. https://bisnis.tempo.co/read/1239558/sri-mulyani-suntik-rp-177-t-untuk-bumn-ekonomberi-peringatan/full\&view $=$ ok.

Darmawi, H. (2019). Manajemen Risiko, Jakarta: Bumi Aksara.

Gewati, M. (2019). Alasan Pemerintah Jokowi-JK Fokus Bangun Infrastruktur. https://money.kompas.com/read/2019/03/26/084500826/alasan-pemerintah-jokowi-jkfokus-bangun-infrastruktur?page=all.

Haris, A. (2009). Pengaruh Penatagunaan Tanah Terhadap Keberhasilan Pembangunan Infrastruktur Ekonomi. 
https://www.bappenas.go.id/files/3013/5228/3483/05abdul_20091014131228_2260_ _.pdf.

Nababan,

$\mathrm{H}$.

(2018).

Risiko

Hukum

Direksi

BUMN. https://majalahmanajemen.wordpress.com/2018/05/11/risiko-hukum-direksi-bumn/.

Ningsih, L. (2020). Laba 4 BUMN Konstruksi Kompak Amblas, Waskita Karya Paling Nahas. https://www.wartaekonomi.co.id/read302390/laba-4-bumn-konstruksi-kompak-amblaswaskita-karya-paling-nahas?page $=3$.

PT. Wijaya Karya Beton (Persero) Tbk. (2016) “Kilas Kinerja 2016” https://investor.wikabeton.co.id/misc/AR/flipbook/2016/208/\#zoom=z.

PT. Adhi Karya (Persero) Tbk. (2019). “Annual Report 2019” https://adhi.co.id/media/content_files/shares/laporantahunan/[ADHI]\%20ANNUAL\%2 0REPORT\%202019\%20\%20FULL_587e1dc91beaf2cdf2284f67c4d09b69617092e5.pd f.

Republik Indonesia. Undang-Undang Dasar Tahun 1945.

Republik Indonesia. Undang-Undang Nomor 40 Tahun 2007 tentang Perseroan Terbatas.

Republik Indonesia. Undang-Undang Nomor 17 Tahun 2003 tentang Keuangan Negara.

Republik Indonesia. Undang-Undang Nomor 19 Tahun 2003 tentang Badan Usaha Milik Negara.

Republik Indonesia. Peraturan Presiden Nomor 18 Tahun 2020 tentang Rencana Pembangunan.

Sastrawidjaya, M.S \& Mantili, R. (2012). Perseoran Terbatas Menurut Tiga Undang-Undang, Bandung: Keni Media.

Sembiring, S. (2012). Hukum Perusahaan Tentang Perseroan Terbatas. Bandung: Nuansa Aulia.

Silondae, A.A. \& Fariana, A. (2013). Aspek Hukum Dalam Ekonomi \& Bisnis, Jakarta: Mitra Wacana Media.

Soekanto, S. (2014). Pengantar Penelitian Hukum. Jakarta: Penerbit Universitas Indonesia (UI Press).

Soekanto, S. \& Mamudji, S. (2003). Penelitian Hukum Normatif: Suatu Tinjauan Singkat, Jakarta: Raja Grafindo Persada.

Zulmawan, W. (2019). Legal Risk Management BUMN, Jakarta: Prenadamedia Group. 